\title{
Mumpsimus and the mything of the individualistic entrepreneur
}

\begin{abstract}
The purpose of this paper is to explore the persistence, in the face of considerable evidence to the contrary, of the notion that entrepreneurship is a purely individualistic practice. It may be that taking account of the dynamics of social conditioning, social interaction and the embedding process is simply too complex to be used as a heuristic, instead the convenient myth of the romantic of the heroic individual holds sway. The methodological issue of an under-socialised concept of entrepreneurship is considered, showing how methodological individualism could easily arise in explanations which risk employing contradictory levels of analysis and explanation. To conceive the entrepreneur as an atomistic and isolated agent of change is to ignore the milieu that supports, drives, produces and receives the entrepreneurial process. The entrepreneurial agent encounters the social, may be shaped by it, but in turn, employs his or her agency to change the structure.
\end{abstract}

\section{Key Words}

Entrepreneurship theory, individualism, networks, myth, entrepreneurial ideology

\section{Introduction}

The purpose of this paper is to explore the persistence, in the face of considerable evidence to the contrary, of the notion of entrepreneurship as a purely individualistic practice. Lindgren and Packendorff (2002) suggest that the entrepreneurship field has adopted some taken-for-granted assumptions, 
including the focus on single individuals, which may hamper its development. The idea of the entrepreneur operating as an atomistic individual - sometimes maverick, often non-conforming, but single-handedly relentlessly pursuing opportunity - is an ideological convenience. Accordingly, the role of this myth is to provide an expedient human identity to a complex socio-economic process; to personalise entrepreneurship by presenting what Bechhofer and Elliot (1981) called the friendly face of capitalism. Johannisson (1998) makes a similar point, arguing that the strong willed individual is much more comprehensible, for both researchers and practitioners, than the complexity of social interplay.

The endurance of the individualised myth can be seen as an example of mumpsimus i. This word has come to be applied to someone who sticks obstinately to their old ways, in spite of the clearest evidence that they are wrong (Robinson, in Arouh, 1987:395, see also Drakopoulos and Karayiannis 2005:68). This may also relate to the case of entrepreneurship as an individualised phenomenon. Entrepreneurship is a new discipline, relatively insecure in its self-perception, and still lacking a coherent and holistic theoretical underpinning (Bygrave (1989: 13) Bygrave and Hofer (1991) Filion (1998) Brazeal and Herbert (1999:29) Shane and Venkataraman, (2000:217)). It may be that our field's immaturity has exacerbated its mumpsimus, our marked reluctance to jettison certain wornout ideas. This suspicion is reinforced by the tendency for us to retain "the models, methods and theories of certain disciplines imported" that are "not the most recent ones but actually those that many times are considered passe”. (Steyaert, 2005:5). 


\section{Constructing The Entrepreneur as Individual Actor}

This essay does not make any sort of case for understanding entrepreneurship purely as a collective; nor does it suggest a primary explanatory power for entrepreneurship at the social level. The entrepreneur must remain in the centre of the entrepreneurial stage. Entrepreneurs capture or produce change, so that entrepreneurship is the manifestation of change. But to conceive this process as entirely individualised seems to be flawed in that it misses how entrepreneurs draw from and give back to the social. The change that is captured is derived from the socio-economic; the change that is produced becomes part of the socio-economic. Thus entrepreneurs are deeply embedded within the society in which they operate (Granovetter, 1985). So to conceive the entrepreneur as an atomistic and isolated agent of change is to ignore the milieu that supports, drives, produces and receives the entrepreneurial process. Even Schumpeter felt compelled to talk about the Socialokonomik, (Swedeberg, 1991) to recognise the social embeddedness of enterprise.

However, just as the present argument is about the limitations of the explanatory power of the under-socialised entrepreneur, this is also true of an over-socialised view. Wrong (1961) pointed out that in some sociologies there was no view which would make it possible to allow for the variation of individual actions to have effects in the explanation of social phenomena. This sort of social determinism may be as flawed as the methodological individualism which we critiqued earlier. For much of the early entrepreneurial literature the issue was that individualistic explanations were seen as a priori true- entrepreneurs are different from others, so that difference must explain what they do. The same sort of argument has been 
applied to unemployment. If it is viewed through an individualistic lens -only some people cannot get jobs; so unemployment is caused by an individual's lack of skills or lack of effort in job hunting. But unemployment can also be quite reasonably explained by structural changes, industrial shift or even by geo-political changes. The problem is thus to try to achieve an explanatory balance which properly allocates individual action within the context of the social.

This issue, sometimes called the structure and agency problem, has a long history. One of the few theoretical solutions to the explanatory dilemma of attributing reasons is Giddens theory of structuration where he attempts to reconcile the duality of structure and agency. Giddens (1984) point is that structure and agency have quite different properties, society is relational and these relations outlast any individual. Thus whilst an individual entrepreneur may have a number of social relationships, entrepreneurship has an enduring relationship with society. This relationship is most often change. Societies do not determine entrepreneurs, nor do entrepreneurs determine society, but they may have considerable impact on each other. Structures are both the medium and the outcome of interactions, both constraining and facilitating human action (Giddens, 1984). Structuration theory accepts the existence of 'objective' structures, which are the result of individuals' own actions. Thus Giddens accords structure a formative position in social action, but also recognises the agents' freedom within the social structure, a freedom to modify the structure. In this way the entrepreneurial agent encounters the social, may be shaped by it, but in turn, employs his or her agency to change the structure. This metatheoretical framework appears to us to present a mechanism which accords 
entrepreneurial agents their due, but also allows us to recognise that the social structure, and the entrepreneurs' relationships with that structure, are an intrinsic part of the entrepreneurial process. By applying this theoretical orientation social structure can be related to entrepreneurial agency.

Consequently, even at a macro social level, we can begin to understand why the GEM (Global Entrepreneurship Monitor) study shows that someone from the USA is five times more likely to become an entrepreneur than someone living in Finland (Arenius and Autio, 2000). Tornikoski (1999) argues that, until recently, Finnish social institutions neither recognised, nor respected entrepreneurship. Thus the social impacted strongly on the attractiveness of entrepreneurship. Indeed Tornikoski shows how entrepreneurship was viewed as different from "normal" human conduct, so that Finnish research focussed on the deviant behaviour of individuals. Moreover, Minniti (2003) emphasises how economic variables have failed to fully explain entrepreneurial variations and suggests that to better understand entrepreneurial behaviour one must look at the importance of the local social environment. Thus whilst the economic environment may explain some of the difference, any convincing explanation must take account of the differences that lie in the social.

The remainder of the paper is structured by first examining the case for understanding entrepreneurship as socially embedded. It then turns to consider reasons why we are so reluctant to change our old mumpsimus. In particular the paper argues that the phenomena of entrepreneurship are socially constructed to present the entrepreneur as a heroic agent of change. 
This social construct is a heuristic, a means of dealing with a complex phenomenon. This simplification is underpinned by at least two founding myths of enterprise. The first is academic, the intuitively appealing but flawed concept of entrepreneurial personality traits. The fundamental attribution error, inherent in trait based explanations, obscures the reality of context and circumstance. The second is populist, the powerful and widespread endowment of the entrepreneur with heroic status that carries with it notions of uniqueness, individuality, non-conformity and distinctiveness. When scholars try to contextualise this modernist myth into the explanatory power of economic theory, for example Schumpertian theory, the individualised entrepreneur is thrown into sharp focus as the agent of change. On the one hand, then, there is an academic striving for explanatory power, especially associated with trait theory; on the other, heroic populist imagery of the entrepreneur. These converge to create a paradigmatic heuristic of the individualistic entrepreneur.

\section{The entrepreneur as a social animal}

Johannisson (1998) suggests that much of the debate concerning the essence of entrepreneurship has placed the individual at the centre, depicting entrepreneurship as the individual adventurously projecting. Cooney (2005:226) argues for a greater recognition of the role of entrepreneurial teams, decrying "one of the great myths of entrepreneurship...the notion of the entrepreneur as a lone hero, battling against the storms of economic, government, social and other environmental forces". Similarly, Lindgren and Packendorff (2002) propose that most conceptual accounts of the entrepreneur are usually embodied in a single person but they argue that entrepreneurship is not the result of what single 
individuals do; it is the consequence of collective organising and social interaction. Nijkamp (2003) noted that the idea of the individual entrepreneurial hero has been pervasive in the SME literature, but suggests that more recently the intricate embeddedness of modern enterprises in global networks has also challenged the position of the 'entrepreneurial hero'. As Pittaway and Rose point out, "past emphasis on individualism and the heroic entrepreneur has already been questionned" (2006: 227). Similarly, the objective of Jones and Conway's paper (2000) is to deconstruct the myth of the entrepreneur as a heroic individual. They note a social perspective requires the acknowledgement that any given entrepreneurial firm is dependent upon many other actors to accomplish all the functions needed. Citing Johannisson and Peterson (1984), they comment upon the apparent paradox that, on one hand, entrepreneurship personifies individualism and independence while on the other hand individuals are dependent on ties of trust and cooperation. Steyaert and Katz (2004) draw on a related point when they relate entrepreneurship and society to suggest that entrepreneurial "space" can be reclaimed in a geographic, discursive and social sense. Drakopoulou Dodd et al (2004) use a stage model to examine entrepreneurship-as-doing, finding that "at each stage in the process, the importance of the social and economic environment, as well as of entrepreneurial cognition, was clear" (2004: 49).

A social dimension focuses on the social processes that shift away from the singular entrepreneur to multiple actors and stakeholders. Zafirovsko (1999:352) is particularly scathing of any explanatory account which portrays entrepreneurship as somehow outside society, "undertaken by insulated and egotistic human Monads". This, he notes, indicates the 
inadequacy of the 'pure' economic theory of entrepreneurship for addressing the complexities of the phenomenon and offer a "sensible alternative" of a multilayered sociological approach to entrepreneurship. The emphasis becomes the wider societal setting within which this behaviour emerges, exists and evolves. Such a social setting for entrepreneurship necessarily includes a variety of networks in that this is how entrepreneurs become embedded in the social (Jack and Anderson, 2002; Uzzi, 1997).

\section{The networked individual: entrepreneurs in their social setting}

The entrepreneurship literature has placed a great deal of attention of late on the importance of entrepreneurial networks and has effectively demonstrated that these are essential to the start-up and growth of a new firm. Organisational scientists, economists and sociologists especially are focusing on (entrepreneurial) networks as a vehicle for understanding how work gets done (Aldrich and Zimmer (1986,) Arocena (1984,) Carsrud and Johnson (1989), Grannovetter (1973; 1985), Harland (1995), Hodgson (1988), Johannisson and Peterson (1984), Malecki and Tootle, (1996, 1997). Ostgaard and Birley (1994), Szarka, (1990)). Entrepreneurial networks have been shown to facilitate opportunity recognition, resource acquisition, the provision of information, as well as providing frameworks for innovation and for the development of regional entrepreneurial environments. Indeed, several researchers have found improvements in the performance of entrepreneurial firms to be linked to effective networking (Hanson, 1995). Increasingly, network studies draw on structuration and social construction to argue that entrepreneurship may perhaps be best understood as a set of inter-relationships and interactions within the opportunity and constraint structures of specific environments. Within the norms and modus operandi 
of their habitus, entrepreneurs invoke trusting responses from others that allow them to co-create and enact visions of future realities, thereby changing the habitus itself (Drakopoulou Dodd et al, 2006).

Given the strength of this evidence of how entrepreneurship involves networked individuals and the networking of individuals, it seems difficult to conceive of entrepreneurship as the isolated act of an individual. A few examples will helpfully illustrate this argument, by looking at the role of others in the initial stages of entrepreneurial venturing. The start of the entrepreneurial process is typically suggested to be the identification of a new business opportunity. It has been shown that even this activity is unlikely to be carried out in an individualistic fashion. For example, Hill et al (1997) found that "network entrepreneurs" - those who use social network contacts to find out about opportunities - recognised many more entrepreneurial opportunities than "solo entrepreneurs". A large weak-tie network, in particular, was found (Singh, 1999) to provide entrepreneurs with an abundance of heterogeneous information leading to recognition of a larger pool of opportunities.

The next steps in the process, evaluating an idea, and accessing resources to translate it into a reality, have equally been shown to involve a number of people beyond the entrepreneur. Alice de Koning (1999) has demonstrated that evaluating opportunities, and assessing the resources available to enact them, as well as opportunity recognition, occur through dialogue with network contacts. De Koning found that for serial entrepreneurs, moving from idea to concept involved dialogue with a tight circle of strong ties, whereas the resource acquisition phase used secondary or weak ties, derived 
from the inner circle. Thorpe et al (2006:235) provide a strong explanation for such processes, pointing out that the socially embedded nature of entrepreneurial learning "means that the entrepreneurial recognition and pursuit of opportunities is a relational awareness of, and creation of, localized possibilities through the social enactment of cognitions". Similarly Zhang et al have shown that the mode and scope of learning interactions with alters in the environment, as well as specific "unique social and business contexts", shape the extent to which an entrepreneurial firm can create product and process innovations (2006:313-314).

These illustrations could be extended throughout the entrepreneurial process, from resource acquisition (Hoang and Antoncic, 2003), and on through venture growth (Larson, 1992:79; Lechner and Dowling, 2003). For example, a recent study of SME buyer-supplier relationships has indicated that "owner-managers leverage social aspects of commercial relationships for the purposes of profit" (Morrisey and Pittaway 2006, 293). As Johannisson and Monsted (1997) argue, it is very likely we should see "contemporary venturing activities as a partial mobilization of a slowly changing overall network". Indeed, the importance of networking to venture success is highlighted by recent evidence that it is the lead entrepreneur in team-starts who takes responsibility for networking, or, perhaps, the key networker in a team who becomes the lead entrepreneur (Neergard, 2005:273).

This all stands as evidence that entrepreneurship is not an individualistic act and clearly shows that at all of the key stages of new venture creation entrepreneurship appears to progress through interaction with others. In addition to the importance of networking to the entrepreneurial process, it is 
also telling that evidence is mounting which indicates that team-based venture creation is more successful on many counts than solo entrepreneurship. (Cooper and Daily (1997), Doutriaux, 1992 Kamm et al., 1990, Fiet et al, 1997, Michel and Hambrick, 1992, Miller, 1983, (Storey, 1994 Teach et al., 1986, Timmons (1994) Vyakarnam et al., 1999; Timmons, 1994). This is especially well-illustrated by the collection of papers presented in a recent special issue of the ISBJ. Matlay and Westhead's (2005) study into virtual entrepreneurial teams within e-tourism found that the key benefits emerging from such communities were access to information of high quality, quantity and reliability; the "inherent pool of sharable human, financial, and knowledge resources", and niche marketing advantages (294295). Disadvantages, on the other hand, included the imposition of group decisions, norms, structures and hierarchies upon (theoretically independent) entrepreneurs (295-296). Vyakarnam and Handelberg remind us that outwith entrepreneurship, the importance of top management teams is ever more recognized, and that there is strong evidence that "businesses owned by teams are more likely to have a greater diversity of skills and competences to draw upon in addition to a wider network of social and business contacts" (237). Clarkin and Rosa re-conceptualise the franchisorfranchisee relationship as a special form of entrepreneurial team, indicating that even this type of tightly contractual interaction may perform better if relationships within in adopt a more team-like, entrepreneurial ethos (326).

\section{Why does this matter?}

There is, then, a strong case for conceptualising the entrepreneur as a social animal, but the need remains to demonstrate that this actually matters. Gartner argued (2001:27) that it is especially important in entrepreneurship 
to examine and articulate the "assumptions we make about this phenomenon". The interdisciplinary nature of the field generates rich diversity, but also confusion and misunderstandings. Tacit assumptions, such as the belief in the individualistic entrepreneur, are particularly troublesome, since they so often go unchallenged. At another more practical level, these individualistic assumptions may mislead prospective entrepreneurs. If they do not know how a network supports, how it facilitates, how it develops enterprise; they may quite easily neglect the effort required to build the social capital necessary to link into the network.

At a more abstract level, as Barthes (1972:143) notes, "A myth does not deny things, on the contrary, its function is to talk about them; simply it purifies them; it makes them innocent, it gives them a clarity which is not that of an explanation, but a statement of fact." He finds that myths lend arbitrary signs which signify the obvious as unalterable sets of connotations. So the myth of the individualised entrepreneurial remains a powerful ideological tool. Ogbor (2000) argues that ideology legitimises, becomes a mask and a weapon. In the entrepreneurial case, such ideology may justify a claim to knowledge, so that research and theory building mirrors the dominant ideology. So (2000:614) "a theory may be 'useful' in terms of its ability to justify and legitimize underlying societal ideologies, myths and assumptions". Although these myths have little analytic value, owing more to rhetoric than reason, it is essential to register the power of the construct. "Men respond to their environment as they see it, rather than how it is." argues Brown (1988:196). So that whilst we may decide that such myths are no more than the glossing of folklorism we cannot dismiss them as 
irrelevant. After all for some, myths clarify and synthesise reality's considerable confusion (Landes, 1969).

\section{Why the myth persists}

This section presents reasons to account for the persistence of the individualised entrepreneur. It begins with a 'methodological' account then turns to consider the social construction of the entrepreneur. Finally it draws these ideas together to show why the individualised entrepreneur has remained so convincing.

One possible explanation lies in the issue of the most appropriate unit of analysis for developing explanatory theory. Entrepreneurship is often talked about as the embodiment of those enterprising qualities and activities that are held dear, such as change and development, so that we expect progress in the modernist sense that somehow tomorrow will be better than today. But entrepreneurship thus conceived is what Nisbet (1970) calls a very broad unit idea. It is both vague and elusive and at this level often defies definition. Yet the thematic power of the concept which embraces its capaciousness also masks its teleological qualities. This is why we so often hear the politicians appeal for more entrepreneurship; entrepreneurship appears as both a descriptor and an explanation. It presents a quasiexplanation and a demonstration, but drained of specificity and a priori true. This is an ideographic trap that as Bryman (1992:11) puts it, is "a seductive but irritatingly intangible way of discussion". Thus when we try to shift the unit of explanation to a unit of analysis, we quite naturally anticipate that we will find entrepreneurship in entrepreneurs. But entrepreneurs, those deemed to practice entrepreneurship, do not do so continuously. 
Entrepreneuring, except for serial entrepreneurs, is usually a one-off event, perhaps revisited occasionally. As Schumpter (1934:74) notes, one "is an entrepreneur only when he actually carries out new combinations".

Consequently even the practice of entrepreneuring is transitory, ephemeral and fleeting, (although entrepreneurial outcomes are both substantive and substantial). It is thus unsurprising that attempts to understand entrepreneurship have focused upon and given explanatory priority to the individualistic level of analysis. This is because the individual entrepreneur is simply the most tangible element of entrepreneurship. The concept of entrepreneurship is fuzzy, entrepreneurial process is complex and often intangible, but entrepreneurs are real people. Nevertheless, it is hard to avoid agreeing with Jones and Spicer's assertion that, at the level of deep discourse the entrepreneur is "an empty signifier...whose operative function is not to 'exist' in the usual sense but to structure phantasmic attachment" (2005: 235).

Moreover, when we take into account how positivism dominates entrepreneurial research publications (McDonald et al, 2002, Grant and Perren, 2002), such an approach requires an object for study, or at the very least an objectifiable reality, we can readily see why process is often neglected and the objectified and "isolated" individual becomes the object scrutinised. Indeed, Bouchikhi (1993) suggests that entrepreneurship research is biased towards successful individuals. Moreover, he claims that even when process is examined this is presented as a consequence of the successful individual. 
Of course we cannot explain all of entrepreneurship by recourse to the social level. The social has some explanatory power, but we must be very cautious about the "ecological fallacy", using the wrong level of analysis. Licht and Siegel (2005) show how two iconic scholars use different levels of analysis to provide different forms of explanation of entrepreneurship. Weber's classic work showed how social values created social movements, such as the Protestant Work Ethic (1990 edition). In contrast Schumpeter (1947) focused on individual motivations. Thus social explanations can provide broad social accounts, but we cannot attribute a social account to explain individual behaviour.

Equally we must be aware of the problems of methodological individualism. For Estler, methodological individualism contends that all social phenomena are explicable only in terms of an individual's propensities, goals and beliefs. "To explain social institutions and social change is to show how they arise as the result of the actions and interaction of individuals," (Elster, 1989; 13). Methodological individualism is an essential part of modern neoclassical economics, which usually analyses collective action in terms of "rational", utility-maximizing individuals. This is the so called Homo economicus postulate. But Lukes (1968) explains how, in the enlightenment, it was recognised that a society was no more decomposable into individuals that a geometric surface can be decomposed into lines. Accordingly, the social does not explain entrepreneurial action, any more than examining an entrepreneur can explain entrepreneurship. Rather both levels, the individual and the social, will, jointly and severally, contribute to understanding. Moreover Giddens' idea of structuration, of the entrepreneur dynamically embedded in society, provides a means of relating the two levels. 
Chiasson and Saunders (2005) illustrate how this can be achieved in relation to a specific aspect of entrepreneurship, when they apply structuration theory to reconcile diverse approaches to opportunity research, including individualism and embeddedness.

\section{The entrepreneur as socially constructed and academically construed}

This section examines the underpinnings of the individualistic myth. First to be considered is the populist image of the heroic entrepreneur, the warrior, single-handedly battling the establishment. This powerful construct has become established as 'the entrepreneur'. Secondly the section explores how early academic entrepreneurial studies echoed this individualism. The explanatory power of these studies, themselves echoing the individualist explanations of psychology and economics, is less well accepted today. Nonetheless they remain superficially attractive because of the conflation, perhaps even confusion, of description of entrepreneurial behaviour and cause.

A study by Nicholson and Anderson (2005) of articles in a highly respected newspaper about entrepreneurs vividly demonstrated the popular image of the entrepreneur as a solitary battler. They noted how such newspapers are a "Greek Chorus", a sense making role; and that "good journalism is popular culture" (2005:158). They argued that metaphors play an important sense making role in how we think and learn about entrepreneurs. Of the ten years sampled, 480 articles were studied and all portrayed the entrepreneur as an individual. "Flamboyant; my hero; gentle giant; masters of time and space" to "likable rogue; polite rebel; ultimate outsider", all peppered the press presentation- but all as an individual! Pitt (1998), Drakopoulou Dodd 
(2002), Koiranen (1995), Hyrsky (1998) and De Koning and DrakopoulouDodd (2002) have adopted a variety of metaphor methodologies and sources to examine social constructions of the entrepreneur, in a range of diverse national settings. Each found vivid examples - warrior, superman, captain, pioneer, sportsman - but once again, all individualised. It seems then, that the popular image of the entrepreneur is the heroic individual. Whilst such social constructions may, or may not, reflect reality; they guide (Chell, 2000) our sense of reality.

As an example of the enduring power of such constructions, consider briefly gender issues. The masculinity of the entrepreneurial myth appears to be reinforced through such images, and has indeed been found to be reproduced within family firms in the dichotomous constructions of the “ 'heroic male' owner-manager and the invisible women' embedded in patriarchal/paternal discourses and practices" (Hamilton, 2006, 267, Hamilton and Smith, 2003). Hamilton finds that whilst such constructions are narrated to present a comprehensible form of family firm to the outside world, the actual practice of management exhibited far more shifting, complex and ever re-negotiated forms of gender relations. Hamilton demonstrates that entrepreneurial families are complicit in the enactment and narration of social constructions of the entrepreneur compliant with dominant myths for external consumption. She also shows that quite different practices may be masked by such narratives. This example shows how the entrepreneurial myth shapes social narratives as constructions of identity and power, even when it is at odds with the lived experiences and internal narratives of an entrepreneurial venture. 
But it is not only in popular imagery that the solitary individual perpetuates. Even in academe, as Curran (1986:17) puts it "Entrepreneurship is a halo word,...this glamorous label is attached to what often turns out on close inspection to be very prosaic activities indeed." Indeed Hornaday (1990:248) suggests that entrepreneurs should be termed "warriors". Casson (1982) declares the entrepreneur to be," a legendary figure who personifies qualities that society believes to be important." Curran (1986:17) however warns as a halo word, its attachment to any activity invests it with "all the cultural meanings and approval to be found in a society which makes the initiation of economic activity the embodiment of the virtues of success, thrift, hard work and inherent ability". Drucker (1986:27) colourfully portrays the entrepreneurial effort as transforming the mundane, since "until recognised, every plant is a weed and every mineral just another rock".

So entrepreneurship appears as a liberating philosophy of individual achievement. It is a doctrine which capitalises, quite literally, on individual effort. Embedded in the myth are whole ideologies of hard work, independence, thrift and a constellation of imputed "Victorian Values". Since Samuel Smiles in 1859, and his Yankee cousin, Alger Hiss, evangelised self help as opportunity, the myth of the individual striving is maintained. Thus the entrepreneur enjoys a rare and heroic status, "men for whom the hazards are an exhilaration" (Cole 1959:103)": the free swinging entrepreneur, unafraid, a folk hero" (Toffler 1985:140), and quoting Pareto, "adventurous souls, hungry for novelty and not at all alarmed at change" (ibid). So that for Collins et al (1964:6), "In the American pantheon of heroic types the entrepreneur is the truly successful common man." 
Drakopoulou Dodd and Anderson (2001) have underlined the rhetorical use to which enterprise culture ideologues have put these myths: "the iconographic importance of entrepreneurial freedom is of no little significance for the enterprise culture" (p21). Thus politicized, the myth of the independent, free, individual entrepreneur has formed, they argue, the bedrock for UK small firms and enterprise policy since the 1980s. This issue, then, is not a trivial one.

\section{Searching for the roots of mumpsimum}

Social constructions, narratives and myths of the entrepreneur help form a unit idea which becomes elevated to a quasi explanation. However, even if we turn to consider explanatory entrepreneurial theory we find a very similar singular entrepreneur. Both (many) psychological and (most) economic theories employ the individual as the unit of analysis which then becomes the unit of explanation. Intuitively, entrepreneurs seem different; they behave differently; take more risks and they are at the very least scarce. So it becomes very tempting to try to explain them in terms of these differences. But as discussed earlier, this methodological individualism is problematic, in that it looks for explanatory power at the level of the individual and consequently neglects other levels.

For personological theories, the individual, their traits and behaviours forms the focus. But the early versions of such trait theory, the search for the crucial characteristic, have been generally discredited in favour of a broader conception (Steyaert, 2005:5, Delmar, 2000, Gartner, 1988; Chell, 1985). Indeed, methodological individualism of this sort has been criticised for its ignoring that reality can only be experienced and mediated by an individual's 
consciousness, which in turn is shaped by the societal reality. This usually means that the impact of the social is forgotten, so that a static perspective is embraced. More sophisticated, socio-psychological approaches, including cognition theory (Barron (1998), Busenitz and Lau (1996), Krueger and Brazeal (1994), Krueger (2000), Mitchell et al (2000)., and socio-economic approaches, such as networking, or population ecology (Aldrich and Weidenmayer (1993), Reese and Aldrich (1995) and, especially, Aldrich and Martinez (2001)), have been increasingly and widely used to explain the relevant aspects of entrepreneurial behaviour and process. All of these focus on the relationship between the entrepreneur and the wider environment.

A different argument applies to economic theories, although they too tend to hold the aggregation of individual decisions as explanation. Economic theories have become well established and we can detect what Bygrave, (1989) called "physics envy", where the very neatness and concision of economic analysis lends an authenticity to such analysis. But the paramount problem with the agglomeration of individual decisions lies in the very nature of entrepreneurship itself. The rationality necessary for homoeconomicus fits poorly with the reality of the contingencies of enterprising. We know that entrepreneurs behave differently, but as Gartner (1988) told us, there are more differences between entrepreneurs than between entrepreneurs and the population. Each entrepreneurial act is something new, so to average such idiosyncratic behaviour to provide explanation becomes difficult. As Schumpeter (1947) noted, economists tend to treat as non existent anything which is not quantifiable. Thus we see the why mainstream "orthodox" neo-classical economic theory remains individualised. 
Arouh (1987, p 415) notes that scholarly mumpsimus has two main causes.

The first is perhaps best explained in Kuhnian terms, as a reluctance to abandon a favoured paradigm, due to the internal dynamics of science. The second links science to its socio-political context, and argues that there may be ideological reasons why a concept or approach is stubbornly retained in the teeth of the evidence. The first answer here seems implausible, since there is no evidence of a substantial rearguard action in entrepreneurship still using the "strict" individualism of trait theory. Even economics, at least that which is Schumpertian influenced, has acknowledged the "socialised man". So whilst there is little evidence of a Kuhnian paradigm shift, there is evidence of a growing scholarly awareness of the social. ii The second reason is much more plausible, the individualised entrepreneur is profoundly ideological. If change can be personified in the entrepreneur; if the formation of new businesses can be attributed an individual's effort, the instrumentality of this ideology, "If she can do it, so can I!", is a powerful concept. It is unsurprising that such an individualised presentation appeals to political players.

\section{Conclusion}

To return to the research question, "why does the myth of the individualised entrepreneur persist?", number of points have been made which hopefully help to answer the question. The popular vision of the entrepreneur has been shown to be profoundly individualistic: people may have difficulty in understanding the concept of entrepreneurship, but they readily identify with an entrepreneur. A commonsense understanding of entrepreneurship infers an individual. It maybe that taking account of the dynamics of social 
conditioning, social interaction and the embedding process is simply too complex to be used as a heuristic, instead the convenient myth of the romantic of the heroic individual holds sway. Consequently, in this way the social construction is individual.

The methodological issue of the under-socialised concept was also considered, and it was shown how methodological individualism could easily arise in explanations which risk employing contradictory levels of analysis and explanation. But most telling was the argument about the unit idea of entrepreneurship. Here it was argued that description becomes conflated with explanation, so that a convincing quasi explanation arises. Vivid descriptions of the freewheeling individual may well accurately describe what some entrepreneurs actually do, but it doesn't describe all entrepreneurs. So these areas - ideology, popular image, heuristic social construction, methodological individualism - all seem to combine to create and sustain our very own mumpsimus.

The dangers of this mumpsimus within the academic sphere lie in the possibility that by over-individualising the entrepreneur, too little account is taken of context. This is every bit as unbalanced and uni-dimensional as over-socialisation. Redressing this balance is an on-going process, and there are many contributions from entrepreneurship scholars which combine structure and agency; and / or social-cultural antecedents and individual cognition; and / or networking processes and individual entrepreneurial action. Nevertheless, the strongly positivist nature of most entrepreneurship research, with its emphasis on the actions of individual entrepreneurs, may be an indication that much remains to be done (McDonald et al, 2004). 
Given the strength of the mythic individualized entrepreneur ideology in our surrounding cultures, this is not, of course, surprising.

For educators, and policy makers the issue is equally important. Social constructions of the entrepreneur outwith the academic sphere have been shown to be still more largely composed of heroic individualized iconography. If one ignores the milieu that supports, drives, produces and receives the entrepreneurial process, how is it possible for effective policies and educational programmes to be developed? Interventions focused solely on the level of the individual, and impregnated with atomistic assumptions about the "nature" of entrepreneurship, are unlikely to prove as effective as those which also engage with structure. It is furthermore possible that this populist hagiography of the atomistic entrepreneur lends especially itself to political rhetorics which espouse a wider vision of the importance of individualism, and is excluded from other, more collectivist political approaches. At the very least, this restricts diversity and plurality in the politics of enterprise. Entrepreneurs, and would-be entrepreneurs, who are routinely exposed to this mythic ideology may also thereby down-play networking and social capital aspects of the entrepreneurial process, which, as we have argued, may be fundamental to sustained survival and success.

The academic field would be well advised to engage more fully with structure and agency in entrepreneurship, and to communicate this multi-dimensional nature of entrepreneurship more effectively to its diverse publics. Perhaps then we can encourage them to trade their old mumpsimus for our emerging sumpsimus. 


\section{References:}

Aldrich, H and Martinez, M (2001) "Many are called, but few are chosen: an evolutionary perspective for the study of entrepreneurship", Entrepreneurship Theory and Practice, Summer 2001, pp 41- 56

Aldrich, H, and Weidenmayer, G (1993) "From Traits to Rates: An Ecological Perspective on Organisational Foundings", in Katz, $\mathrm{J}$ and Brockhaus, R (1993) pp145-196

Aldrich, H.E. and Zimmer, C. (1986). "Entrepreneurship through social networks" In D. Sexton and R. Smilor, (Eds.), The art and science of entrepreneurship. New York: Ballinger Publishing Company.

Arenius, P., Autio, E., 2000, GEM, Finnish Executive Report, http://www.gemconsortium.org/download/1161591802562/GEM2000Finni sh.pdf

Arocena, J. (1984). "Le genie et le carnet d'adresses". Autrement, 59: 182187.

Arouh, A (1987) "The mumpsimus of economists and the role of time and uncertainty in the progress of economic knowledge", Journal of Post-

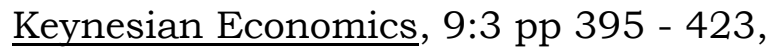

Barron, R. (1998), "Cognitive Mechanisms in Entrepreneurship - Why and When Entrepreneurs Think Differently Than Other People". Journal of Business Venturing, 13, 275-294.

Barthes, R (1972) Mythologies, London: J. Cape,

Bechhofer, F., Elliot, B., (1981) The petite bourgeois; a comparative study of the uneasy stratum, Macmillan, London

Bouchikhi, H., (1993), "A Constructivist Framework for Understanding Entrepreneurship Performance", Organization Studies, Vol. 14, No. 4, pp. 549-570. 
Brazeal, D and Herbert, T (1999) "The Genesis of Entrepreneurship". Entrepreneurship Theory and Practice, Spring 1999 v23 i3 p29

Brown JAC (1988) The Social Psychology of Industry Penguin Harmondsworth

Bryman, A. (1992) Charisma and Leadership in Organizations, Sage, London

Busenitz, L and Lau, C. (1996) "A Cross-Cultural Cognitive Model of New Venture Creation" Entrepreneurship Theory and Practice 20(4):25-39

Bygrave, W. D., (1989), "The Entrepreneurship Paradigm (2); Chaos and Catastrophe Among Quantum Jumps?" Entrepreneurship Theory and Practice, $14(1): 7-30$

Bygrave, W. D. and Hofer, C. W., (1991), "Theorizing About Entrepreneurship", Entrepreneurship Theory and Practice, 16(2): 13-22

Carsrud A. and Johnson R. (1989) "Entrepreneurship: A social psychological perspective". Entrepreneurship and Regional Development, 1, 21-31.

Casson M (1982) The Entrepreneur, An Economic Theory Martin Robertson, Oxford.

Chell, E (1985) “The Entrepreneurial Personality: A Few Ghosts Laid to Rest” International Small Business Journal 3:3

Chell, E., (2000) "Towards researching the "opportunistic entrepreneur': A social constructionist approach and research agenda", European Journal of Work and Organizational Psychology, Volume 9, Number 1, 63 - 80

Chiasson, M and Saunders, C (2005) "Reconciling diverse approaches to opportunity research using the structuration theory", Journal of Business Venturing, 20, 747- 767 
Clarkin, JE and and Rosa, PJ (2005) "Entrepreneurial Teams within

Franchise Firms" , International Small Business Journal International Small

Business Journal 23 (3) 303-332

Cole, A (1959) Business Enterprise in its Social Setting Harvard University Press, Cambridge MA

Collins, OF, Moore, DG, Unwalla, DB (1964) The Enterprising Man Michigan State University Business Studies, Michigan

Cooney, T (2005) "Editorial: What is an Entrepreneurial Team?" International Small Business Journal International Small Business Journal 23 (3) 226235

Cooper, AC and Daily, CM (1997) "Entrepreneurial Teams" in Sexton, DL and Smilor, RW (eds) Entrepreneurship 2000, pp127-500, Upstart Publishing, Chicago IL

Curran J (1986) Bolton 15 years on: A Review and Analysis of Small Business Research in Britain 1971-1986 Small Business Research Trust London

De Koning, A (1999) Opportunity formation as a socio-cognitive process. In P.D. Reynolds, W.D. Bygrave, S. Manigart, C.M. Mason, G.D. Meyer, H.J. Sapienza and K.G. Shaver (Eds.), Frontiers of Entrepreneurship Research. Wellesley, MA: Babson College.

de Koning, A and Drakopoulou Dodd, S 2002) "Raising babies, fighting battles, winning races: entrepreneurial metaphors in the media of 5 English speaking nations", Presented at the 2002 Babson Kauffman Entrepreneurship Conference, Boulder, Colorado

Delmar, F (2000) "The Psychology of the Entrepreneur", in Carter, S and Jones-Evans D (eds), Enterprise and Small Business; Principles, Practice and Policy, Prentice Hall, London 
Doutriaux, J (1992" "Emerging High-technology Firms: How Durable are their Comparative Start-up Advantages", Journal of Business Venturing 7 (4): $303-22$

Drakopoulos, SA and Karayiannis, A (2005) "A Review of Kuhnian and Lakatosian 'Explanations' in Economics”, History of Economic Ideas, XIII/2005/2, 51-73

Drakopoulou Dodd, S (2002) "Metaphors and Meaning in the Narratives of Entrepreneurs", Journal of Business Venturing 17:5

Drakopoulou Dodd, S and Anderson, A (2001) "Understanding the enterprise culture: paradigm, paradox and policy" International Journal of Entrepreneurship and Innovation, Feb 2001, 13-26

Drakopoulou Dodd, S, Anderson, A and Jack S (2004) "A Review of Entrepreneurship as Doing: The Importance of Socio-Cultural and Economic Environment", IBAT Journal of Management, 1:2, 37-53

Drakopoulou Dodd, S, Jack, S and Anderson, A (2006) “"Entrepreneurship as the nexus of change: the syncretistic creation of the future", presented at the 2006 Organisation Studies Summer Workshop, Mykonos, June 2006

Drucker, PF (1986) Innovation and Entrepreneurship Pan London

Elster, J., (1989). Nuts and Bolts for the Social Sciences. Cambridge, Cambridge University Press.

Fiet, J, Busenitz, L, Moesel, M and Barney, J (1997) "Complementary Theoretical Perspectives on the Dismissal of New Venture Team Members", Journal of Business Venturing 12(5): 347-66

Filion, L. J., (1998), "Entrepreneurship: Entrepreneurs and Small Business Owner-managers", in The State of the Art in Small Business and Entrepreneurship, Ed., P-A. Julien, Ashgate, Aldershot. 
Gartner, WB (1988) "Who is the Entrepreneur? Is the Wrong Question", American Journal of Small Business 13 (Spring) pp. 11-32.

Gartner, W (2001) "Is there an elephant in entrepreneurship? Blind assumptions in theory development." Entrepreneurship Theory and Practice, Summer 2001, pp27-39

Granovetter, M. (1973). "The strength of weak ties". American Journal of Sociology, 78(6), 1360-1380.

Granovetter, M. (1985). "Economic action and social structure: The problem of embeddedness". American Journal of Sociology, 91(3), 481-510

Grant, P and Perren, L (2002) Small business and entrepreneurial research: Meta-theories, paradigms and prejudices, International Small Business Journal, 20 (2): $185-211$

Giddens A., (1984), The Constitution of Society, Cambridge: Polity Press.

Harland, C.M. (1995) "Networks and globalization: A review of research", EPSRC Final Report. Grant No. GRK53178.

Hamilton, E (2006) "Whose story is it anyway? Narrative Accounts of the Role of Women in Founding and Establishing Family Businesses" International Small Business Journal 24(3) 253 - 271

Hamilton, E and Smith, R (2003) "The Entrepreneuse: A Silent Entrepreneurial Narrative" in 2003 Proceedings of the Small Business and Entrepreneurship Development Conference, University of Surrey, April 2003 pp 183-92. Shipley: European Research Press

Hansen, E. (1995). "Entrepreneurial networks and new organization growth". Entrepreneurship Theory and Practice, 19(4), 7-21.

Hills, G.E., Lumpkin, G.T. \& Singh, R.P. (1997). “Opportunity recognition: Perceptions and behaviours of entrepreneurs." In P.D. Reynolds, W.D. 
Bygrave, N.M. Carter, P. Davidsson, W.B. Gartner, C.M. Mason and P.P. McDougall (Eds.), Frontiers of Entrepreneurship Research. Wellesley, MA: Babson College.

Hoang, H and Antoncic, B ((2003) "Network-based research in entrepreneurship: A critical review", Journal of Business Venturing 18:2, 165-187

Hodgson, G (1988) Economics and Institutions, Polity Press, Oxford

Hornaday JA (1990) "Dropping the E-words from Small Business Research: An Alternative Typology" Journal of Small Business Management, 28(4) 2233

Hyrsky, K. (1998) "Entrepreneurship; metaphors and related concepts", Journal of Enterprising Culture, 6(4) 391-412

Jack, S.L. and Anderson, A.R. (2002). "The effects of embeddedness on the entrepreneurial process". Journal of Business Venturing, 17(5): 467-487.

Johannisson, B., (1998) "Entrepreneurship as a collective phenomenon", paper presented at RENT XII, Lyon, 26-27 Nov.

Johannisson, B. \& Peterson, R. (1984) "The Personal Networks of Entrepreneurs", Third Canadian Conference, International Council for Small Business, Toronto, May 23-25

Johannisson, B and Monsted, M (1997) "Contextualizing Entrepreneurial Networking", International Journal of Management and Organization Fall $199727: 3$ pp $109-137$

Johannisson, B. (2000) "Networking and Entrepreneurial Growth", in The Blackwell Handbook of Entrepreneurship, D. Sexton \& H. Landstrom, (eds.), Oxford: Blackwell p134-158 
Jones, O., Conway, S., 2000, "The social embeddedness of entrepreneurs; a re-reading of "Against the Odds", Aston working paper series, RP 0023, Aston University Birmingham

Jones, C and Spicer, A (2005) "The Sublime Object of Entrepreneurship", Organization, Vol. 12, No. 2, 223-246

Kamm, JB, Shuman, JC, Seegar, JA and Nurick, AJ.(1990) "Entrepreneurial Teams in New Venture Creation: A Research Agenda", Entrepreneurship Theory and Practice 14(4):7-17

Krueger, N and Brazeal, D (1994) "Entrepreneurial Potential and Potential Entrepreneurs". Entrepreneurship Theory and Practice, 18(3): 91-105.

Krueger, N., (2000), “The Cognitive Infrastructure of Opportunity Emergence.".Entrepreneurship:Theory and Practice, 24(3): 5-26.

Koiranen, M., (1995) North European metaphors of entrepreneurship and an entrepreneur. In Bygraves, W.D., Birley, S., Churchill, N.C., eds. Frontiers of Entrepreneurship Research, 203-216, P \& R Publications, Waltham MA

Landes D (1969) The Unbound Prometheus Cambridge University Press Cambridge

Larson, A (1992) "Network Dyads in Entrepreneurial Settings: A Study of the Governance of Exchange Relationships" Administrative Science Quarterly 37 (1992): 76- 104

Lechner, C and Dowling, M (2003) "Firm networks: external relationships as sources for the growth and competitiveness of entrepreneurial firms". Entrepreneurship and Regional Development 15 pp1-26

Licht, A.N., Siegel, J.I. (2005) “The Social Dimensions of Entrepreneurship”, forthcoming in eds Casson, M., Yeung, B., Oxford Handbook of Entrepreneurship, Oxford University Press, Oxford. 
Lindgren, M., Packendorff J., (2002) "Interactive entrepreneurship-On a study of innovative social process", Paper presented at Euram, Stockholm, May 9-11

Lukes, S.(1968) Methodological Individualism Reconsidered, British Journal of Sociology, 19 (2), 119-129

Malecki, E. and Tootle, D. (1996). "The role of networks in small firm competitiveness". International Journal of Technology Management, 11(1/2), 43-57.

Malecki, E. and Tootle, D. (1997). "Networks of small manufacturers in the USA: Creating embeddedness". In M. Taylor and S. Conti, (Eds.), Interdependent and uneven development: Global-local perspectives, pp.195221. Aldershot: Ashgate.

Matlay, $\mathrm{M}$ and Westhead, $\mathrm{P}$ (2005) "Virtual Teams and the Rise of $e$ Entrepreneurship in Europe", International Small Business Journal, International Small Business Journal 23 (3) 279-302

McDonald, S., Gan, B.C., Anderson, A.R., (2002) "Studying Entrepreneurship: A review of methods employed in entrepreneurship research 1985-2004", a paper presented at RENT, Copenhagen, June

Michel, JG and Hambrick, DC (1992), "Diversification Posture and the Characteristics of Top Management Team", Academy of Management Review 23 (2):242-66

Miller, D (1983) “The Correlates of Entrepreneurship in Three Types of Firms”, Management Science 29(7):770-91

Minitti, M, (2003), Entrepreneurship and network externalities, paper presented at the workshop, Entrepreneurial Process: Research perspectives, Harvard University, May, 2003 
Mitchell, R., Smith, B., Seawright, K., Morse, E. (2000) "Cross-cultural Cognitions And The Venture Creation Process" Academy of Management Journal Oct 200 43:1 p974

Morrisey, JW and Pittaway, L (2006) "Buyer-Supplier Relationships in Small Firms: The Use of Social Factors to Manage Relationships" International Small Business Journal 24(3) 272-323

Neergaard, H (2005) "Networking Activities in Technology-based

Entrepreneurial Teams” International Small Business Journal, International Small Business Journal 23 (3) 257-278

Nicholson, L., Anderson, A R. (2005) News and Nuances of the Entrepreneurial Myth and Metaphor: Linguistic Games in Entrepreneurial Sense-Making and Sense-Giving. Entrepreneurship Theory and Practice 29 (2), 153-172.

Nijkamp,P., (2003) "Entrepreneurship in a Modern Network Economy" Regional Studies, 37 (4), 395-405

Nisbet, R, (1970) The sociological tradition, Heineman, London

Ogbor, J. O (2000) "Mythicizing and Reification in Entrepreneurial Discourse: Ideology-Critique of Entrepreneurial Studies" Journal of Management Studies 37; 5, 605-636

Ostgaard, T.A. and Birley, S. (1994). "Personal networks and firm competitive strategy - A strategic or coincidental match?" Journal of Business Venturing, 9, 281-305.

Pitt, M (1998) “A Tales of Two Gladiators: 'Reading' Entrepreneurs as Texts.” Organization Studies 19: 3 p 387.

Pittaway, L and Rose, M (2006) "Learning and Relationships in Small Firms: Introduction to the Special Issue", International Small Business Journal 24(3) 227-226 
Reese P. and Aldrich H. (1995) "Entrepreneurial networks and business performance". In S. Birley and I.C. MacMillan, (Eds.), International entrepreneurship. London: Routledge.

Schumpeter, JA (1934, this edition 1993), The Theory of Economic

Development, Transaction, New Brunswick

Schumpeter JA (1947), The Creative Response in Economic History The Journal of Economic History, Vol. 7, No. 2, 149-159.

Shane, S and Venkataraman, S (2000) "The Promise of Entrepreneurship as a Field of Research", Academy of Management Review, Jan 2000 v25 i1 p217

Singh, R., Hills, G.E., Hybels, R.C. \& Lumpkin, G.T. (1999). "Opportunity recognition through social network characteristics of entrepreneurs". In P.D. Reynolds, W.D. Bygrave, S. Manigart, C.M. Mason, G.D. Meyer, H.J. Sapienza and K.G. Shaver (Eds.), Frontiers of Entrepreneurship Research. Wellesley, MA: Babson College.

Steyaert, C (2005) "Entrepreneurship: in between what?: on the 'frontier' as a discourse of entrepreneurship research", International Journal of Entrepreneurship and Small Business, 2(1), 2 - 16

Steyaert, C., Katz, J., (2004) "Reclaiming the space of entrepreneurship in society: geographical, discursive and social dimensions”. Entrepreneurship \& Regional Development, 16 (3), 179-196.

Storey, DJ (1994) Understanding the Small Business Sector Routledge, London

Swedeberg, R., (1991) Joseph A. Schumpeter: His life and Work, Polity Press, New York 
Szarka, J (1990) "Networking and small firms". International Small Business Journal, 8, 10-22.

Teach, RD, Tarpley, FA and Schwartz, RG (1986) "Software Venture Teams", in Ronstadt, R, Hornaday, JA, Peterson, R and Vesper, KH (eds) Frontiers of Entrepreneurship Research pp546-62, Babson College, Wellesley, MA

Thorpe, R, Gold, G, Holt, R and Clarke, J (2006) "Immaturity: The Constraining of Entrepreneurship" International Small Business Journal 24(3) 232-252

Timmons, J (1994) New Venture Creation: Entrepreneurship for the $21^{\text {st }}$ Century, Irwin, Cambridge MA

Toffler, A (1985) Future Shock Pan London

Tornikoski, E., (1999) "Entrepreneurship and theory development; The use of the constructivist approach in theorizing process", http://www.sbaer.uca.edu/research/icsb/1999/20.pdf

Uzzi, B (1997). "Social structure and competition in interfirm networks". Administrative Science Quarterly, 42(1): 37-70.

Vyakarnam, S and Handleberg, J (1999) "Exploring the Formation of Entrepreneurial Teams: the Key to Rapid Growth", Journal of Small Business and Enterprise Development 6(2):153-65

Vyakarnam, S and Handelberg, J (2005) "Four themes of the Impact of Management Teams on Organizational Performance: Implications for Future Research of Entrepreneurial Teams" , International Small Business Journal 23 (3) 236-256

Weber, (1990 edition) The Protestant Ethic and the Spirit of Capitalism, (Translated Parsons, T 1930), Allen Unwin, London 
Wrong, D., (1961) "The oversocialized conception of man in modern society", American Sociological Review, 26(2), 183-193

Zafirovski, M, (1999) "Probing into the social layers of entrepreneurship: outlines of the sociology of enterprise", Entrepreneurship and Regional Development, 11 , (4) 351-371

Zhang, M, Macpherson, A and Jones, O (2006) "Conceptualizing the Learning Process in SMEs: Improving Innovation through External Orientation" International Small Business Journal 24(3) 299 - 323

\footnotetext{
${ }^{\mathrm{i}}$ According to folklore, there was once a medieval monk who persistently said a phrase in the Latin Eucharist wrongly. Instead of "quod in ore sumpsimus", he would say "quod in ore mumpsimus". Now sumpsimus is Latin for "we have taken", but mumpsimus is just nonsense. What made this particular mistake memorable, according to the version of the incident told in 1517 by Richard Pace, was when the monk stated that he had said it that way for forty years and "I will not change my old mumpsimus for your new sumpsimus".

ii Indeed, and ironically, the continued application of Kuhnian philosophies within the Social Sciences has itself been recently attacked as a form of mumpsimus, which inhibits the application of more modern and relevant theories drawing on developments within the sociology of scientific knowledge and cultural history (Drakopoulos and Karayiannis 2005:68).
} 